\title{
Impact of Investor Sentiments on Future Trading
}

\author{
Basheer Ahmad \\ Iqra University, Karachi \\ Usman Ali Warraich \\ Indus University, Karachi \\ Sidra Saeed \\ SZABIST, Karachi
}

\begin{abstract}
Purpose: This study bridges the gap between future trading prospects and information required to mold investors' sentiments so s/he could devise better future trading strategies.

Methodology/Sampling: This study takes all companies which trade the futures on the KSE. This study used the monthly data of the futures trading, stock return, stock turnover, high-low ratio and the realized volatility. The data is taken from January 2008 to December 2012 to test investor sentiments impact on future trading. Companies' data is retrieved from the official website of KSE. The thirty-eight companies' data is used in this study.

Findings: The contrivance of future trading relationship with the investor sentiments is appraised in this study. The main difference between this and the previous discourse is that we construct the futures trading model that employ the investor sentiments.

Practical Implications: The verdict of this study holds the important useful implications particularly as consideration of investor sentiments in the presence of the futures trading in Pakistan.
\end{abstract}

Keywords: Volatility, Stock turnover, Investor Sentiments.

JEL Classification: D 920, E 220, F 210

\footnotetext{
* The material presented by the authors does not necessarily portray the viewpoint of the editors and the management of the Institute of Business \& Technology (IBT).

* Basheer Ahmad: drbasheer@iqraisb.edu.pk

* Usman Ali Warraich: warraich.u.a@gmail.com

* Sidra Saeed: sidra.ghr@gmail.com

CJMSS is published by the Institute of Business and Technology (IBT). Main Ibrahim Hydri Road, Korangi Creek, Karachi-75190, Pakistan.
} 


\section{INTRODUCTION}

This study bridges the gap between future trading prospects and information required to mold investors' sentiments so s/he could devise better future trading strategies.

The dilemma is that trading activities sometimes do not result into expected returns that leave the investors clueless for future trading.

Therefore, investors rely on volatility measures by forecasting a suitable model but the question related to its estimation remains pertinent as no frequency has been determined yet. Hence, the only resort left is to apply the model on future trading.

\section{RESEARCH OBJECTIVES}

The investors' sentiments are very much reflected in their trading decisions and their mental agility also exerts a great influence while selecting a right commodity. However, future trading is a new kind of investment opportunity that allows the investor to gain high returns at reduced risk.

\section{PROBLEM STATEMENT}

The rationale behind investment is to make safer ones and this notion sometimes leads the investors towards risk-aversive behavior or they stick to the commodities that offer lower returns. Moreover, investor sentiments reflect their mindset and the urge to earn quick money may create high volatility in the financial markets. This study has shed light on disturbance created in the market and ultimately its impact on future trading.

\section{RESEARCH QUESTIONS}

This research will explicitly address the following questions:

Q1. What is the impact of investor sentiments on future trading when unpredictability prevails in the market?

Q2. Does the investor's sentiment create overreaction in the futures trading market?

Q3. Does future trading lead the investor sentiments or investor sentiments lead the future trading?

Futures trading activities are increased for the safe passage for the high risk volatility of stock; these new techniques are introduced in the new era of the financial markets as a new innovation to give the investor the best hedging option for their selection of portfolios. In the future trading all the three main players will avidly participate: hedgers, arbitragers and speculators. Hedgers usually take the edge of their future risks, arbitrager use opposite strategy of the hedger and speculators always speculate to make money, so the three players invest with an aim to reduce their risk exposure. This will provide the market to operate more efficiently, liquefy and less volatile. Investors involved in the future trading are linked with their commitment to trade, sentiments of the investor that prevails in the market plays the key role in the decision process of the investors. The irrational behavior of the investors usually appears in the market which will let the market to overreact (Sheu and Wei 2011). Futures trading based on investor 
sentiments is based on the trading of their selection criteria of the hedging, price discovery and portfolio selection.

The prognostic influence of investor sentiments impact on the stock market, return and volatility has been examined in the number of papers but with mixed results. Brown and cliff (2004), investigate the relationship between the investor sentiments and their stock market return. Brown found that the sentiments affect the return; but in a negative way they defined two types of investors individual and institutional. He finds that the individual investor sentiments are not helpful in predicting return but institutional sentiments do. Schmeling (2009) investigated the sentiments and stock return across the countries and finds that the investor sentiments are helpful in forecasting average return across the countries. Different anomalies are studied in the previous studies which are used to capture the effect of the investor sentiments impact on different derivative markets, macro as well as micro variables which are observed and studied by the investor for market investment strategies; these create different biases for investor so the practical approach leads to different imperfect measures of measuring investor sentiments abstracted from the investor physiology. Baker and Wurgler (2006) construct the model to measure the investor sentiments impact on the stock return, finding of the six anomalies such as IPO, first day return of the IPOS, dividend premium, trading volume, the closed end funds discount, and stocks turnover.

\section{SIGNIFICANCE OF THE STUDY}

Despite the vast text that has inspected the impact of investor sentiments on the future trading, little agreement has emerged. Furthermore, hardly any study has been conducted so far to examine the effect of investor sentiments on the future trading with respect to Pakistan's market. This study will help the investors, policy makers, financial analysts and regulators to predict the results of introducing options. Estimates of investor sentiments will help the future pricing of the contracts in the market (Baker \& Wurgler 2006). This study helps the portfolio managers to recognize the height of risk which they can tolerate and evade risk by making well-organized portfolios. This study will present researchers with enhanced comprehension of Pakistan's investor sentiments. This will cause new ways for canvassers to intensely estimate the Pakistan's market.

The aftermaths of 2008 suspended the market for almost four (4) months. Analysts thought that this is due to the financial crisis occurring worldwide and some says that this is due to the investor sentiments in stock markets. This study will examine whether the investor sentiments are accountable for the vital disaster of 2008 or not.

\section{ORGANIZATION OF THE STUDY}

This study is planned as follows. Section 1 reviews the literature regarding the previous studies contribution, main role of investor sentiments in financial markets, volatility and stock return. Section 2 examines the dependent and independent variables of the study. Section 3 includes the data, methodology, sample taken and tools used to undertake the study. Section 4 discusses the outcomes of the study and section 5 appraises the conclusion drawn from the results. 


\section{LITERATURE REVIEW}

As the competition and volatility increase in the market that let the financial institutions to find the new markets and the investors to make rational decisions and increases the opportunity for diversifying the risk. Investments sentiments affect the future trading and derivative market as prescribed in many studies (e.g., Karpoff ,1987, Edwards ,1988).volatility had a small or little interference is observed in many studies, as investor sentiments are not much higher in the future trading (e.g., Edward 1998, Aggarwal ,1988). Future trading volatility increase is observed in the studies which show that the volatility is increased in the developed market but there is no volatility observed in the underdeveloped market (Lee and Ohk 1992).

De Long et al. (1990) construct the model to study the investor's risk, sentiments and return in financial markets. Speculators normally invested in the high risk assets to get high return but the other sophisticated investor, sometimes speculators make non risky asset risky to get high returns. The prices that move away from the fundamental value relapse to their original price in the long term and this take long time. Speculators are the main players of the financial market that will help in increasing or decreasing the price of the risky asset if mispriced. There is a lead-lag relationship between the cash volatility and future trading and studies present different results for them (e.g., Weaver and Banarjee, 1990, Shalen, 1993, Chen, 1995, Fung and Patterson 1999). Hedgers are usually interested in open interest and it suits them so they are inclined towards their sentiments (Chang 2000).

\subsection{Investor sentiments: Good or Bad}

The prognostic influence of investor sentiments impact on the stock market, return and volatility has been examined in the number of papers but with mixed results. Brown and Cliff (2004), investigate the relationship between the investor sentiments and their stock market return. Brown found that the sentiments affect the return; but in a negative way and they defined two types of investors: individual and institutional. Findings reveal that the individual investor sentiments are not helpful in predicting return but institutional sentiments do. Schmeling (2009) investigated the sentiments and stock return across the countries and finds that the investor sentiments are helpful in forecasting average return across the countries. Culture is the unchangeable observable fact in any country so the sentiments and return of the cross countries do not affect others.

Chang et al. (2012), Xindan and Bing (2008) and Palomino (2009) showed that local sports loss create sentiments and that have a negative impact on the stocks return. Surprising loss created bearish sentiments in the investor and which results in the low return. Results showed that small firms are more affected by the sports sentiments then large firms. Palominos (2009) mentioned that market has expectations and information gain before the game start but due to less information, sentiments have negative impact on the return. Overreaction and abnormal returns follow the game outcomes. Chiang et al (2011) examined the investor behavior when the stock bubble arises. Stock prices diverted from their fundamental values and show overreaction and foreign investment is increased in the country. Hoarding behavior is used to create bubbles in the market which makes the investor earn high return. Results showed that the investor to invest in the stocks having less foreign investment which prevent them from overreaction. Shah and Gong (2012) explained that the disaster affect the sentiments of the investor which subsequently affect the stock return. This study shows events' effect on investor 
sentiments, return and stocks which enjoy a strong relationship, but the firm size is also affected as small firms are more affected than large firms. Qiang and Shu-e (2009) appears to analyze the relationship of sentiments, volatility and return. They used the GARCH-M model; they find out that positive changes have a great impact than the negative impact of sentiments on the stock price and return. There are many studies which show that the investor sentiments affect at the corporate level and ultimately their investment decisions. Grundy and $\mathrm{Li}$ (2010) developed a model to explain corporate level investment that increases with their investor optimism and that the positive investor sentiments, exceptive compensation and investment decisions are interlinked and depict progress of the shareholders wealth. Kling and Gao (2008) explained that the past returns summary is very important regarding investor sentiments while for investment decisions; if the historic returns are positive then this will generate optimistic behavior of the investor whereas negative past returns are more sensitive for the investor than the positive historic returns. Schuppli and Bohl (2010) did a natural experiment whether foreign investor can destabilize the Chinese market; it is obvious that the institutional or individual investor's sentiments evolve in the market, the results show that the shocks of the sentiments can destabilize the market but the foreign investors can help to stabilize the market, so the foreign investment help in the stabilization of the Chinese market. D.Kourtidis et al. (2011) identifies different traits of the investor that influence their sentiments: risk aversion and cultural bindings. The data is collected from different surveys to provide support to their arguments. The result shows that the higher the investors profile the serious their performance is.

\subsection{Investor, trading and volatility}

Individual's sentiments regarding trading strategies and price of the stock, the decision time to sell (buy) the stock has been extensively discussed in previous literature. Wang et al. (2012) said trading pattern of the stock prices repeats after a certain time period. Different investor groups are studied in this study and their behavior in market according to the trading signals and price formation rules. Griffin and Zhu (2006) study focus on the information of the investors according to which they make trading decisions, they showed that the margin of favored game players are those investors who have information. The class period is very important in the whole process of trading of stocks and informed investor can only take benefit from it.

Verma and Soydemir (2009) investor irrational behavior is ignored by the rational traders in the market who bring the price back to the fundamental value. When irrational investors are optimistic at that time the stocks are overvalued, this study has collected data from two different surveys and the result shows that the optimistic behavior of the rational traders don't change the market price risk. The closing time period of the spot and future index are different, spot market closes when the trading is still happening on the future index. The overreaction is studied in the spot market, when the optimism of the investor is removed; the prices come back to its reasonable value. Fung and Lam (2004) A.Salm and Schuppli (2010) examined that the future trading can be the best option for the investor to hedge their risk of the spot market, the noise from the future index might destabilize the spot market. Chau et al. (2011) study examines that the feedback of the positive sentiments created by trading of the past returns of the investors, if investors have positive returns then the behavior of the investors are optimistic. Stotz and Dominik (2012) inside traders have a very important role in the market regarding buying and selling of stock, the value of stock if hold by insider is considered valuable by other investors. The insiders focus on the buying of the stock more, the retail investor used to 
copy the decisions of insider; results show the abnormal gains of the retail investor. Nam et al. (2008) construct the model to describe the retail investor sentiments about the loss aversion attitude where they are reluctant to sell the stock from the fear of loss. Nicolosi et al. (2009) and Finter et al. (2012) examine the investors learning behavior improved by the experience, so adjustment of trading observed and high performing returns and the trading quality improvement of the investor is seen. New investors in the market have to get the advice for their investment from the experienced ones. Changsheng and Yongfeng (2012) examine that the investor sentiments bullish behavior can led the stock's performance high as the excess margin of returns are observed. Changes in investor sentiments showed the movement of changes in the return. The study shows that the valuation by the investor in stocks have difference. The EGARCH model is used for the estimation of the results. Lu et al. (2012) examines the investor sentiments are time variant in the stock market return, investors have to understand their sentiments to have their corrective decisions.

Bansal et al. (2010) examines that the volume in the stock index affect on the T-bonds pricing, so the stock market negativity effective on the future contracts even when the inflation is stable. Whereas Bohl et al. (2011) examines that spot trading index does not impact on the future trading. Wang et al. (2011) develop a model to study the investor behavior in the future market and showed that the complete and incomplete information in hand of investors affect their decision of investment. Lee et al. (2011) examines that the trading imbalance is same as the stock and future trading of buying and selling which is going to affect the future cash. Hsueh et al. (2008) examines that the future trading is the best opportunity for the investors hedging and speculation activities. Cash trading creates volatility in the future trading, trading hours matters a lot for the investors in the future trading. This study explain two different markets and observed that both have different observations. Wang et al. (2009) examines the future markets investor sentiments by using SWARCH model to find the changes in them and find out the volatility is due to investor sentiments. Results show that sentiments have a relationship with the derivative markets, and volatility in the market is due to the investors sentiments, investor profit making performance is also estimated.

\subsection{Investor sentiments anomalies}

Different anomalies are studied in the previous studies which are used to capture the effect of the investor sentiments impact on the different derivative markets, macro as well as micro variables which are observed and studied by the investor in the market investment strategies; these create different biases in the investor so the practical approach leads to different imperfect measures of measuring investor sentiments abstracted from the investor physiology. Baker and Wurgler (2006) construct the model to measure the investor sentiments impact on the stock return, finding of the six anomalies such as IPO, first day return of the IPOS, dividend premium, trading volume, the closed end funds discount, and stocks turnover. In his study he find that proxies have a negative impact on the small stock return, high volatile stocks, non-dividend payers stocks, non-profitable stocks and high growth stocks. Initial public offering has a long run effect in many studies which influence investor sentiments for the long run and increase their enthusiasm. Trading volume is used to measure the liquidity of the stock by the investor sentiments and divided premium is most importantly predicting the security of the investment. .The trading volume anomalies is further examined in models by the Schmeling (2009), Bauer et al., (2009) ,Bohl et al., (2010), Al-hajieh et al., (2011),Joseph et al., (2011), and Akthar et al., (2012) forecasting of the abnormal returns and trading volume due to the investor sentiments. 
Yu and Yuan (2011) explained the narrative device that sentiments to move stock prices, three main anomalies are taken in the study to estimate the sentiments of the investor: first is initial public offering, second is the short position and third is the traders' variance. These three variables are linked to the cognitive biases of the investor, further four different volatility models were estimated in the study Garch $(1,1)$, asymmetric Garch $(1,1)$, rolling window model and the mixed data sampling approach. Results show that the investor sentiments have a strong impact on the mean-variance relationship (Joseph et al., 2011). There are other proxies which affect the sentiments globally. Baker et al., (2012) studied six global and six local indices. Five different proxies were used in this study volatility premium, volume of Initial public offering, first day return of initial public offering, market turnover and dollar value. Siamese twins are taken to check the global and local impact of the investor sentiments.

The results show that global and local sentiments used to predict the market return. In the broad study, there are other investor anomalies which are going to affect the stock prices in the long run which cannot be hedged and arbitrage Stambaugh et al., (2012) explained by eleven new anomalies which are used for the financial asset overpriced study purpose as well informed investors do not have any disgustingly undervalued securities, mostly they don't want to sell their undervalued securities so that will make some investments overvalued. These anomalies have a strong impact on the investor sentiments in best times, which make the securities prices overvalued in that period and the period in which sentiments of investors are low then most of stocks be inclined those of the rational investors, in that time mispricing is less, so mispricing is more studied in the high sentiments periods (Berger and Turtle, 2012, Chung, Hung and Ye, 2012).The all three models were used. Shey and Wei (2011) examined future volatility which is going to be affected or increased by the options market, anomalies were used as dependent and control variables of the derivative market. Volatility is due to the investor sentiments that has been proved in this study, forecasting of the model is done by the regression based forecasting tests.

\subsection{Theoretical framework}

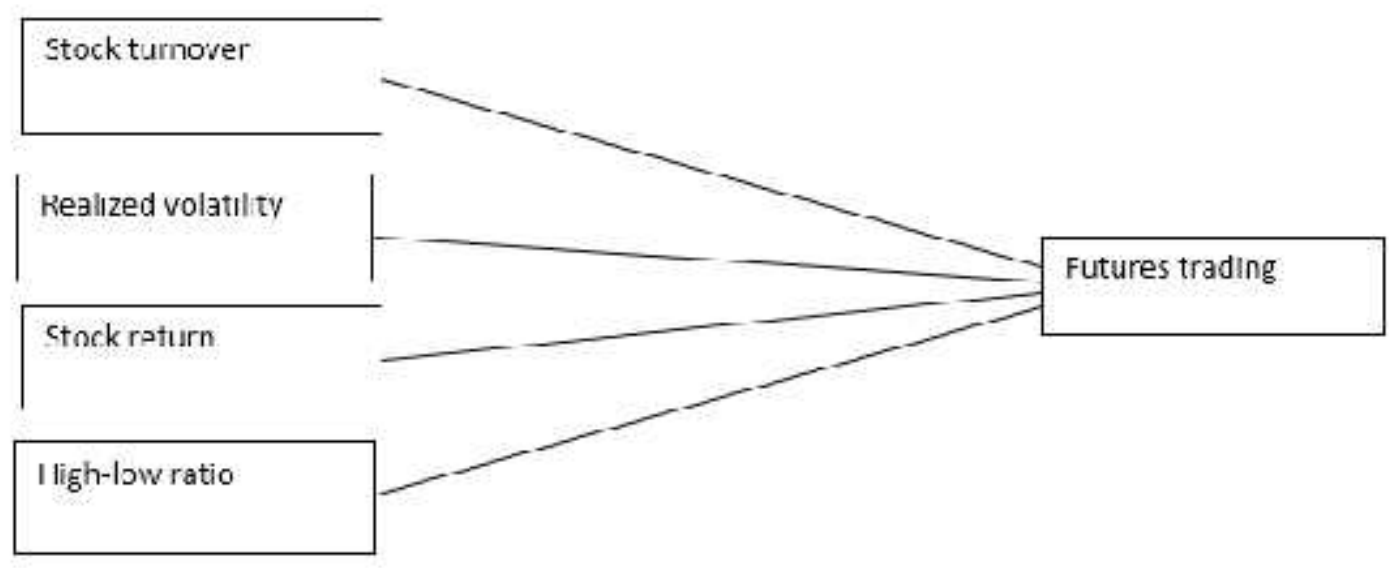

\subsection{Futures Trading and Sentiments Anomalies}

A future trading is defined as the dependent variable in this study and four investor sentiments anomalies were introduced as the independent variables: stock turnover, stock return, realized volatility and high-low ratio which are explained as below. 


\subsubsection{Future trading}

Futures' trading is taken as the dependent variable in this study. Futures trading in former studies is calculated as the daily trading volume and the changes in the open interest (Hsueh et al., 2008; Garcia et al. 1986). WhereVt and OIt symbolize aggregate volume traded and open interest number of contracts of futures on day $t$ across all outstanding contracts, respectively. The important advantage of utilizing this equation by Garcia et al., (1986) explains that this equation is used to stop the possible ending consequences on trading behavior, as the trading volume and open interest are together the function of time to ending the ratio of closing volumes in excess of open interest as defined below:

$$
\mathrm{FT}_{\mathrm{t}}=\frac{\mathrm{VT} t}{\mathrm{OI} t}
$$

\subsubsection{Sentiments anomalies}

Sentiments four anomalies are defined as below as the independent variables in this study.

\subsubsection{Stock turnover}

Many earlier studies explained the stock turnover anomaly as it explains the liquidity that can be examined as the investor's sentiments predictors and market reaction so it can be acting as the trading signals of the security (Baker et al., 2012, Cooper, 1999; Grossman, \&Wang, 1993). The high turnover ratio is pointed towards the irrational investor trading but also entails that market over reaction (Baker \& Wurgler, 2007). The stock turnover ratio is estimated by the volume of turnover to the number of shares listed on the KSE 100 and in this study it is presented as the stock return.

\subsubsection{Realized volatility}

Previous studies show that the realized volatility is used as the standard predicting model (Barndorff-Nielsen \& Shephard, 2002) this variable is used to capture the effect of the investor sentiments volatility on the daily basis. This anomaly is used as the mood gauge estimator for the investor sentiments and the overreaction effects in the future trading is caught by the anomaly. Calculation is done by taking the square of the daily return. The two-fifty days were taken as the trading days of the KSE 100. The estimate is defined as follows.

$$
R V=\left(|\rangle_{i=0}^{a}\left(\ln \frac{P t+i}{P t+i-1}\right)^{2} \times \sqrt{252}\right.
$$




\subsubsection{Stock return}

Previous studies have estimated that anomaly considers the effect of the optimistic investor (e.g., Baker and Wurgler 2006; Stambaugh et al., 2012). As the investor studies the stock prices moving high the sentiments of the investor increases so the overreaction is seen in the market at the period of high optimism. Stock return is observed on the daily basis by the investor in spite of the closing prices of the preceding trading daylight hours.

$$
\mathrm{R} t=\ln \left(\frac{\mathrm{P} t_{t}}{P_{t-1}}\right)
$$

\subsubsection{High-low ratio}

The fourth anomaly used in this study is to check the effect of the volatility measure by the daily data which can estimate the high-low ratio (Sheu et al., 2011; Engle and Gallo 2006) daily observation of the increase of the high-low ratio creates the increase in the optimism of the sentiments of both rational and irrational investor sentiments. Estimation of the high-low ratio is done in this study on the previous obtains all trade in order into explanation, and the latter is built on the basis of quotes sampled at separate intervals. The movement of the HL is observed to the quantity of variation relative to price the price difference for every day.

$$
R_{t}=\left(\frac{H_{t}-L_{t}}{P_{t-1} \times 14 \%}\right)
$$

\subsection{Hypothesis}

H1: Stock turnover impact on the futures trading

$\mathrm{H} 2$ : Realized volatility impact on the futures trading

H3: Stock return impact on the futures trading

H4:High-low ratio impact on the futures trading

H5: There is a relationship between the investor's sentiments and futures trading

\section{METHODOLOGY}

\subsection{Sample}

Karachi stock exchange is the main securities exchange market present in Pakistan. The national stock exchange is having 660 listing companies at the present time. The KSE history is as old as Pakistan itself. It started progressing but showed mixed results till 1991. After liberation KSE becomes energetic. In 1991, KSE-100 index was established and is known as market weighted index comparison of 100 companies. There are thirty-four sectors present so the selection of companies is one from each sector and the rest sixty-six companies were selected on the basis of their market capitalization. 


\subsection{Data}

This study takes all companies which trade the futures on the KSE. This study used the monthly data of the futures trading, stock return, stock turnover, high-low ratio and the realized volatility. The data is taken from January 2008 to December 2012 to test investor sentiments impact on future trading. Companies' data is retrieved from the official website of KSE. The thirty-eight companies' data is used in this study.

\subsection{Research General Methods}

The investor sentiments four anomalies were computed according to the formula, this study uses the unbalanced panel of 2228 monthly observations on 38 companies. It is known that OLS along panel data with cross-sections and unit of time points possibly violate the OLS suppositions. The panel data used in this study is composed of the multiple companies' observations concluded time within the particular unit (company), these observations could be correlated with one another because of the omnipresence of immeasurable unit-characteristics time-consistent factor. Covertly time-consistent individuality in regression equation is converted into the error term, give rise to the heterogeneity bias. When unit is companies panel data may accountable to Heteroskedasticity, which is observed in this study data to reduce it the use of natural log of taken of the futures trading (dependent variable). Further the fixed effect model has been used for the function of better unmeasured time-consistent effects.

Table 1

Descriptive statistics

\begin{tabular}{crrrr}
\hline & \multicolumn{1}{c}{ Minimum } & \multicolumn{1}{c}{ Maximum } & \multicolumn{1}{c}{ Mean } & \multicolumn{1}{c}{ Std. Deviation } \\
\hline \hline Futures trading & .288064219 & $6.876523300 \mathrm{E} 6$ & 1.14563424 & 3.246962231636 \\
Stock Turnover & 9.268609280 & $6.037310000 \mathrm{E} 8$ & 4.03839963 & 6.149317202508 \\
Stock Return & -.177276420 & .144451917 & 7.5405388581 & 1.06997916212 \\
RV & .000000000 & 2.814175929 & 2.98128698 & 2.133495730185 \\
HL & .000000000 & $1.246426087 \mathrm{E} 1$ & 3.48335655 & 7.920607598229
\end{tabular}

This table presents the descriptive statistics of the KSE-100 index, sentiment proxies such as stock turnover, stock return, realized volatility and high-low ratio. Period January 2008 to December 2012

This table presents the descriptive statistics of the KSE-100 index, sentiment proxies such as stock turnover, stock return, realized volatility and high-low ratio. Period January 2008 to December 2012.

Table 1 accommodates the descriptive statistics of the data. To judge the distributional properties of the futures trading, stock turnover, stock return, realized volatility and high low ratio, the collection of descriptive statistics is reported, that consists of minimum, maximum, mean and standard deviation. 
It showed that mean value of stock return is 7.5406 which has the highest mean value. Standard deviation values shows that if any random fluctuation takes place in the independent variable then what will be its effect on the dependent variable. 
Table 2 Correlations

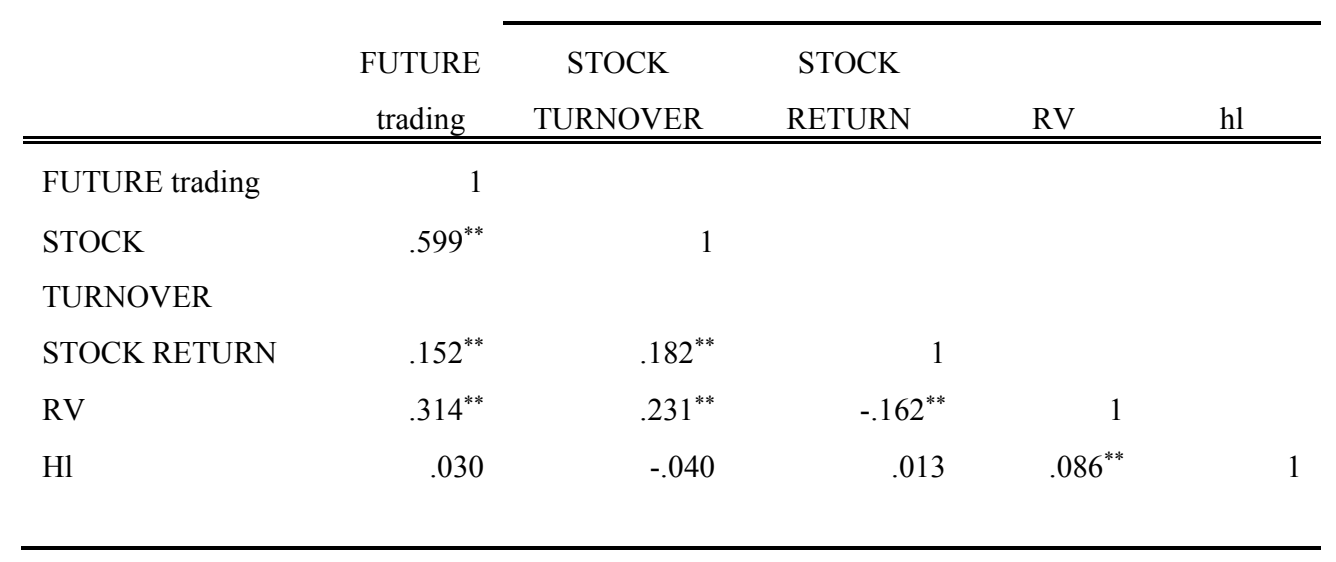

**. Correlation is significant at the 0.01 level (2-tailed).

The correlation matrix is showing the level of relationship among variables. The results of correlations are computed, there are no missing values. The correlation is showing the level of relationship among variables. The results indicate that all variables are correlated with each other, 0.162 shows that RV is strongly and negatively correlated with Stock return. No multicollinearity is observed among variables.

\section{Fixed effect model}

The equation for the fixed model is follows,

$$
\ln F T_{i t}=\propto_{0}+\propto_{1} S T_{i t}+\propto_{2} S R_{i t}+\propto_{3} R V_{i t}^{i}+\propto_{4} H L_{i t}+u_{i}+v_{i t}
$$

Where $\ln F T_{I T}$ is the futures trading of the companies for the company $\mathrm{i}$ at time $\mathrm{t}(i=1, \ldots ., N ; t=1, \ldots ., T)$; 'ST' is the stock turnover of the companies, SR is the stock return, RV is the realized volatility and HL is the high-low ratio of the companies. Volatility effects are covered by the realized volatility and high-low ratio. These variables vary with time but keep constant at given time, $u_{i}$ is the company specific fixed effects, and $v_{i}$ is the idiosyncratic disorder term. 
TABLE 3

Fixed Effect Model

\begin{tabular}{lcccr}
\hline \multicolumn{1}{c}{ Constructs } & Coefficients & Std error & $\mathrm{T}$ & Sig. \\
& & & & \\
\hline Intercept & 8.019 & .076 & 105.586 & $.000^{* *}$ \\
Stock turnover & $2.145 \mathrm{E}-8$ & .000 & 29.320 & $.000^{* *}$ \\
STOCK RETURN & 33.464 & 4.140 & 8.084 & $.000^{* *}$ \\
RV & 2.008 & .211 & 9.526 & $.000^{* *}$ \\
Hl & -.011 & .054 & -.197 & .844 \\
\hline
\end{tabular}

Note: $\mathrm{R}^{2}=0.377, \mathrm{R}=0.614, \mathrm{p}, 0.000 * \mathrm{p}<0.05, * * \mathrm{p}<.001, \mathrm{~F}=336.942\left(.000^{\mathrm{a})}\right.$

Table 3 introduces the results of the fixed effect model; this model shows H1, the stock turnover impact on the future trading is proved as shown in the model that this anomaly is significant at the $1 \%$ level. The second hypothesis of the study is the impact of stock return on the future trading which is accepted as anomaly is accepted at the 1\% significance level. The third hypothesis of the study is also accepted as the realized volatility impact on the futures trading is proved at the $1 \%$ significant level, realized volatility proves the fact that the overreaction is created in the future trading by the decisions of the investor sentiments and the fourth hypothesis is that the high-low ratio impact on the future trading is rejected even at the 5\% level. This appears that the investor sentiments revolve in the futures trading and had a wide impact on their trading behavior and the futures trading market. Overall the model is significant. R2 is also acceptable which 0.377 is. The last hypothesis is that the investor sentiments had a relationship with the future trading and the three anomalies of the investor sentiments is proved in this study and the intercept of the study is significant at the level of $1 \%$ which shows that still there are other anomalies impact on the futures trading.

\section{CONCLUSION}

The contrivance of future trading relationship with the investor sentiments is appraised in this study. The main difference between this and the previous discourse is that we construct the futures trading model that employ the investor sentiments. The best of this study is that contrivance of the futures trading anomalies is based on the predominant model. This study also bonds the gap between the investor sentiments and their decision behavior of investment in the trading.

The contrivance is entrenched by course of the following impressions. First the study of conceivable of the sentiments anomalies for the futures trading markets is placid such as the stock return and stock turnover ratio which is the anomaly defines the investor fears barometer. Second the investor irregular behavior relationship is measured between the investor sentiments and futures trading is inspected to confirm the augur capability of sentiments gauge. Third the forecasting gauge anomalies were used based on the criterion of the forecasting 
index, including the high-low ratio and the realized volatility. Fourth the companies' data is employed for the estimation of the model and data has been gathered from the KSE. Fifth data is the panel data this study used the fixed effect model for the estimation of the data.

The model tests support that the relationship between the investor sentiments and future trading, gives the proof that the stock turnover, stock return and realized volatility have impact on the future trading. The anomalies stock turnover, stock return and realized volatility is best considered by the investor sentiments widely for the future trading.

In cessation our factual findings accede with the investors explanations of their agent carry of their investor sentiments to the companies' strategies which affect the future trading market. The results of the model also define that the investor role easily seen in the market as the creator the overreaction in the market. This study assume that the anomalies of investor sentiments confirms the decisions of investors that employ in the future trading and trading contrivance used in this study also takes the volatility barometers which can be applied to further arbitrations.

\section{PRACTICAL IMPLICATIONS}

The verdict of this study holds the important useful implications particularly as consideration of investor sentiments in the presence of the futures trading in Pakistan. As the investor sentiments creates the overreaction in the futures trading market in Pakistan and the relationship is highly significant, with the implementation of this research in the electronic trading market helps all kinds of investors in their decision process of the future trading and act as a decision support system.

\section{FUTURE RESEARCH DIRECTIONS}

Investor sentiments research may build up additional role of other financial anomalies as a gauge of measurement of the sentiments for example book to market ratio, debt ratio, and initial public offering etc. Further the individuals and institutions sentiments impact on the futures trading can be studied. The other economic sources which are thought to be responsible for the instability in the financial market role can be studied further for example policy impact, financial crisis, rectification of capital institutions etc.

\section{REFERENCES}

Akhtar, S., Faff, R., Oliver, B., \& Subrahmanyam, A. (2012). Stock salience and the asymmetric market effect of consumer sentiment news. Journal of Banking \&Finance, 36, 3289-3301.

Alimov, A., \&Mikkelson, W. (2012). Does favorable investor sentiment lead to costly decisions to go public? Journal of Corporate Finance, 18,519-540.

Baker, M., \& Stein, C, J. (2004). Market liquidity as a sentiment indicator. Journal of Financial Markets, 7, 271-299.

Baker, M., Wurgler, J., \&Yuan, Y. (2012). Global, local, and contagious investor sentiment. Journal of Financial Economics, 104,272-287. 
Bansal, N., Connolly, R., \& Stivers, C. (2010).REGIME-SWITCHING IN STOCKINDEX AND TREASURY FUTURESRETURNS AND MEASURES OFSTOCK MARKET STRESS. The Journal of Futures Markets, 30(8), 753-779.

Bauer, R., Cosemans, M., \& Eichholtz, P. (2009). Option trading and individual investor performance. Journal of Banking \& Finance, 33, 731-746.

Ben-Rephael, A., Kandel, S., \&Wohl, A. (2012). Measuring investor sentiment with mutual fund flows. Journal of Financial Economics, 104,363-382.

Berger, D., \&Turtle, J, H. (2012). Cross-sectional performance and investor sentiment in a multiple risk factor model. Journal of Banking \&Finance, 36, 1107-1121.

Bohl, M., Salm, C., \& Wilfling, (2011). B. Do individual Index futures Investors Destabilize the underlying spot market? The Journal of Futures Markets, 31(1), 81-101.

Bohl, T, M., Goodfellow, C., \& Bialkowski, J. (2010). Individual investors surpass their reputation: Trading behavior on the Polish futures market. Economic Systems, 34,480-492.

Brown, G.W., \&Cliff, M.T. (2004).Investor sentiment and the near-term stock market. Journal of Empirical finance, 11, 1-27.

Brown, W, G., \& Cliff, T, M. (2004). Investor sentiment and the near-term stock market. Journal of Empirical Finance, 11, $1-27$.

BURDEKIN, R., \& REDFERN, L. (2009). Sentiment effects on Chinese share prices and savings deposits: The post-2003 experience. China Economic Review, 20, 246-261.

Chang, S., Chen, S., Chou, R. k., \& Lin, Y. (2012). Local sports sentiments and return of locally headquartered stock: A firm level analysis. Journal of Empirical finance, 19, 309-318.

Changsheng, H., \&Yongfeng, W. (2012). Investor Sentiment and Assets Valuation. Systems Engineering Procedia, 3, $166-171$.

Chau, F., Deesomsak, R., \& Lau, M. (2011). Investor sentiment and feedback trading: Evidence from the exchange-traded fund markets. International Review of Financial Analysis, 20,292305.

Chiang, M., Tsai, I., \& Lee, C. (2011).Fundamental indicators, bubbles in stock returns and investor sentiment. The Quarterly review of Economics and finance, 51, 82-87.

Choy, S.K., \& Wei, J. (2012). Option trading: Information or differences of option? Journal of Banking and Finance, 36, 2299-2322.

Chung, S., Hung, C., \&Yeh, C. (2012). When does investor sentiment predict stock returns? Journal of Empirical Finance, 19, 217-240.

Delong J B, Shleifer A, Summers L, et al. Noise trader risk in financial markets. Journal of Political Economy, 1990, 98(4): 703-738.

Finter, P., Niessen-Ruenzi, A., \&Ruenzi, S. (2012). The impact of investor sentiment on the German stock market. Z Betriebswirtsch, 82,133-163.

Fung, A., \& Lam, K. (2004).Overreaction of index futures in Hong Kong. Journal of Empirical finance, 11, 331-351.

Griffin, A, P., \& Zhu, N. (2006).Are All Individual Investors Created Equal? Evidence from Individual Investor Trading around Securities Litigation Events. Journal of Contemporary Accounting \&Economic, 2(2), 123-150.

Grundy, B. D., \& Li, H. (2010). Investor sentiments, executive compensation and corporate investment .Journals of Banking and finance, 34, 2439-2449. 
Hajieh, H., Redhead, K., \& Rodgers, T. (2011). Investor sentiment and calendar anomaly effects: A case study of the impact of Ramadan on Islamic Middle Eastern markets. Research in International Business and Finance, 25, 345- 356.

Hsueh, P., Liu, Y., \& Lee, N. (2008) Dynamics of Volatility, Futures Trading, and Investor Sentiments under Different Market Conditions. International Research Journal of Finance and Economics.20, 151-163.

Joseph1, K., Wintoki, B, M., \& Zhang, Z. (2011). Forecasting abnormal stock returns and trading volume using investor sentiment: Evidence from online search. International Journal of Forecasting, 27, 1116-1127.

Kling, G., \& Gao, L. (2008). Chinese institutional investor's sentiment. Int. Fin. Markets, Inst. and Money, 18, 374-387.

Kourtidis, D., 'Sevi'c, Z., \& Chatzoglou, P. (2011). Investors' trading activity: A behavioral perspective and empirical results. The Journal of Socio-Economics, 40, 548- 557.

Kumar, A. (2007). Do the diversification choices of individual investors influence stock returns? Journal of Financial Markets, 10, 362-390.

Kurov, A. (2010). Investor sentiment and the stock market's reaction to monetary policy. Journal of Banking \&Finance, 34, 139-149.

Lee, H., Chien, C., \& Liao, T. (2012). Commonality in trading activity and futures-cash basis: Evidence from the Taiwan Futures and stock markets. The Journal of Futures Markets, 32(10), 964-994.

Lee, W., Jiang, X, C., \& Indro, C, D. (2002). Stock market volatility, excess returns, and the role of investor sentiment. Journal of Banking \& Finance, 26, 2277-2299.

Liao, T., Huang, C., \&Wu, C. (2011). Do fund managers herd to counter investor sentiment? Journal of Business Research, 64, 207-212.

LU, X., LAI, K., \& Liang, L. (2012). DEPENDENCE BETWEEN STOCK RETURNS AND INVESTOR SENTIMENT IN CHINESE MARKETS: A COPULA APPROACH.J SystSciComplex, 25, 529-548.

Nam, J., Wang, J., \& Zhang, G. (2008). Strategic trading against retail investors with loss-aversion .International Review of Economics and Finance, 17, 45-55.

Nicolosi, G., Peng, L., \& Zhu, N. (2009). Do individual investors learn from their trading experience? Journal of Financial Markets, 12,317-336.

Palomino, F., Renneboog, L., \& Zhang, C. (2009). Information salience, investor sentiment, and stock returns: The case of British soccer betting. Journal of Corporate finance, 15, 368-387.

Qiang, Z., \&Shu-e, Y. (2009).Noise Trading, Investor Sentiment Volatility, and Stock Return. System Engineering-theory and practice, 29(3), 40-47.

Salm, C., \& Schuppli, M. (2010). Positive feedback trading in stock index futures: International evidence. International Review of Financial Analysis, 19, 313-322.

Schmeling, M. (2009). Investor sentiments and stock returns: some international evidence. Journal of Empirical finance, 16, 394-408.

Schuppli, M., \& Bohl, M. T. (2010). Do foreign institutional investors destabilize China's A-share markets? Int. Fin. Markets, Inst. and Money, 20, 36-50.

Shah, L., \& Gong, S, X. (2012) Investor sentiments and stock return: Wenchuan Earthquake. Finance Research letters, 9, 36-47.

Sheu, H., \& Wei, Y. (2011). Effective options trading strategies based on volatility forecasting recruiting investor sentiment. Expert Systems with Applications, 38, 585-596. 
Stambaugh, F, R., Yu, J., \& Yuan, Y. (2012). The short of it: Investor sentiment and anomalies. Journal of Financial Economics, 104, 288-302.

Stotz, O., \&Georgi, D. (2012). A logit model of retail investors' individual trading decisions and their relations to insider trades. Review of Financial Economics, 10(10), 1-9.

Verma, R., \& Soydemir, G. (2009). The impact of individual and institutional investor sentiment on the market price of risk. The Quarterly Review of Economics and Finance, 49, 1129-1145.

Wang, Yu-Min., Li, Chun-Au., \& Lin, Cha-Fei. (2009).The Impact of Investor Sentiment on the Futures Market: Evidence from the Taiwan Futures Exchange. International Research Journal of Finance and Economics, 28, 134-151.

Wang, Yu-Min., Li, Chun-Au., \& Lin, Cha-Fei. (2011). Investor sentiment spillover effects between the futures and spot markets. Investment Management and Financial Innovations, 8(1), 63-71.

Xindan, L., \& Bing, Z. (2008). Stock market behavior and investor sentiment: Evidence from China. Front. Bus. Res. China, 2(2): 277-282.

Yu, J., \&Yuan, Y. (2011). Investor sentiment and the mean-variance relation. Journal of Financial Economics, 100, 367-381. 